\title{
Knowledge and Behavior Change of People Living with HIV through Nutrition Education and Counseling
}

\author{
Perubahan Pengetahuan dan Perilaku Orang yang Hidup dengan HIV \\ melalui Konseling dan Edukasi Gizi
}

\author{
Fitri Hudayani*, Ratu Ayu Dewi Sartika**
}

*Nutrition Instalation of Dr. Cipto Mangunkusumo Public Hospital, Jakarta, Indonesia ** Public Health Nutrition Department, Faculty of Public Health, Universitas Indonesia, Depok, Indonesia

DOI: http://dx.doi.org/10.21109/kesmas.v10i3.947

\begin{abstract}
HIV, AIDS and nutrition are interconnected. In the HIV Integrated Care Unit of Dr. Cipto Mangunkusumo Public Hospital, nutrition education and counseling services are provided within a collaborative service for people living with HIV (PLWH). This study aimed to determine influence of nutrition education and counseling to knowledge and behavior of PLWH. This study was conducted with quasi experimental design using treatment and control groups. The treatment group consisted of 25 samples and 29 samples for control group. Samples were adults between $18-50$ years old selected by applying inclusion and exclusion criteria. A pretested questionnaire was used to assess knowledge. Paired t-test sample was used to analyze data. This study was conducted on May - July 2014. Based on results of this study, there was effect in form of knowledge change ( $p$ value $=0.000$ ) with score 6.38 point lower on the control group and any significant differences in behavior change ( $p$ value $=0.048$ ) for the treatment group after receiving nutrition education and counseling. This study shows that nutrition and counseling using media of education which is more complete and continuously provided may improve knowledge and change behavior of PLWH. Keywords: Behavior, counseling, education, knowledge, people living with HIV
\end{abstract}

\footnotetext{
Abstrak

HIV, AIDS, dan gizi saling berhubungan. Pada Unit Pelayanan Terpadu HIV Rumah Sakit Umum Pusat Nasional Dr. Cipto Mangunkusumo, layanan edukasi dan konseling gizi disediakan secara kolaboratif untuk orang yang hidup dengan HIV. Penelitian ini bertujuan untuk mengetahui pengaruh pendidikan dan konseling gizi terhadap pengetahuan dan perilaku orang yang hidup dengan HIV. Penelitian ini dilakukan dengan desain kuasi eksperimental menggunakan kelompok perlakuan dan kontrol. Kelompok perlakuan terdiri dari 25 sampel dan 29 sampel untuk kelompok kontrol, di-
}

lakukan sebelum dan setelah perlakuan. Sampel berusia dewasa antara 18 - 50 tahun dipilih dengan menerapkan kriteria inklusi dan eksklusi. Sampel uji-t berpasangan digunakan untuk menganalisis data. Penelitian ini dilakukan pada bulan Mei - Juli 2014. Berdasarkan hasil penelitian, diketahui bahwa adanya efek berupa perubahan pengetahuan (nilai $p=0,000$ ) dengan nilai 6,38 poin lebih rendah pada kelompok kontrol dan terdapat perbedaan yang signifikan dalam perubahan perilaku (nilai $p=0,048$ ) untuk kelompok perlakuan setelah menerima edukasi dan konseling gizi. Penelitian ini menunjukkan bahwa edukasi dan konseling gizi menggunakan media edukasi yang lebih lengkap dan diberikan secara berkelanjutan dapat meningkatkan pengetahuan dan mengubah perilaku orang yang hidup dengan HIV.

Kata kunci: Perilaku, konseling, edukasi, pengetahuan, orang yang hidup dengan HIV

\section{Introduction}

Human immunodeficiency virus (HIV), acquired immune deficiency syndrome (AIDS) and nutrition are interconnected in which condition of HIV and AIDS contributes to malnutrition and the malnutrition condition may have a negative effect on people living with HIV/AIDS (PLWHA). Malnutrition affects the strength and disrupted body immune system resulting susceptibility to infectious diseases, hence increase nutritional needs. The side effects of malnutrition that can cause inability to meet nutritional needs may lead patients to eas-

Correspondence: Fitri Hudayani, Nutrition Instalation of Dr. Cipto Mangunkusumo Public Hospital, Jl. Diponegoro No. 71 Jakarta, Phone: 02131902959, e-mail: fitrihudayani@gmail.com 
ily get infection risk, proving the strong relation between nutrition, HIV and AIDS. ${ }^{1-3}$ Less nutrition and HIV infection have a negative effect on individuals, households and the environment as well, rising from a decrease in clinical condition, nutrition status, quality of life and economic condition. ${ }^{2}$ Obviously, nutrition plays an important role in maintaining the health and immune system and to slow the progress of HIV to AIDS. 4

Moreover, as a consequence of HIV infection, malnutrition also increases the prevalence of cardiovascular disease and insulin resistance among people living with HIV (PLWH) after receiving antiretroviral therapy (ART). This is also an issue of concern. ${ }^{2,5}$ ART aims to slow replication but does not eliminate the virus. PLWH are able to maintain quality of and prolong their life, but they must be in a condition that includes ART, other drugs and food consumption which affect their absorption, metabolism, distribution and excretion resulting a less favorable circumstances. ${ }^{1}$

A study in Tanzania observed that the prevalence of metabolic syndrome was higher in urban than rural areas among individuals living wih HIV and receiving ART. They also observed that components of metabolic syndrome including high blood level of triglycerides, low blood levels of high-density lipoprotein (HDL) and raised fasting blood glucose were significantly high among study participants from urban than those from the rural areas. The traditional predicting risk factors including high level of education, gender and being past or current alcohol consumer significantly predicted the prevalence of metabolic syndrome among participants in the urban area. This study suggests an intervention to prevent the risk, such as reduction of body weight, eating healthy diet and participating at moderate or vigorous intensity activities. ${ }^{6}$

Relation between HIV and malnutrition greatly affects the progress of the disease among PLWH, and interactions that occur may decline health status, nutritional status, quality of life and ultimately affect the productivity of family. At individual level, malnutrition is caused by inadequate intake, then the direct effects are metabolism problem of nutrients at the stage of absorption, storaging and utilization of nutrients in the body which could harm the immune system causing nutrient deficiency and development of infectious diseases. ${ }^{1}$

In improving condition of PLWH through optimization of nutritional status, it is necessary to intervene with health promotion including nutrition education and counseling. ${ }^{1}$ The nutrition intervention program includes nutrition assessment, nutrition education and counseling, food assistance, micronutrient supplementation and activities to strengthen household food access addressed to PLWH. ${ }^{7}$

Theory of planned behavior known as the theory of reasoned action which is an individual's health behavior is directly influenced by intention to engage in that behavior. Three factors affecting behavioral intention include attitude, subjective norm and perceived behavioral control. ${ }^{8}$

The HIV Integrated Care Unit of Dr. Cipto Mangunkusumo Public Hospital collaborates services including nutrition education and counseling services targeted to PLWH. The aim of collaborating such services is to improve and maintain optimal nutritional conditions that may support general health. This study aimed to determine effects of nutrition education and counseling on knowledge and behavior of PLWH.

\section{Method}

A quasi-experimental study was conducted between May and July 2014 with one group using pretest and posttest design. Analysis was based on data from knowledge and implementation of energy intake, food habit and food safety. Respondents were adult patients (18 - 50 years old). Respondents $(n=54)$ were out patients who came to HIV Integerated Care Unit of Dr Cipto Mangunkusumo Hospital Jakarta with inclusion and exclusion criteria. Inclusion criteria were ability to communicate and willing to attend nutrition education and counseling every two weeks. Exclusion criteria were HIV positive with stage 3 and 4 based on World Health Organization (WHO)'s criteria, getting pregnant, not already receiving ART and suffering a chronic disease that affects the diet, such as diabetes mellitus, hypertension and heart disease. This study received ethics and permits approved by Faculty of Medicine Universitas Indonesia Ethical Commitee for Research and the obtained informed consent from each respondent.

Knowledge assessment was conducted by providing a questionnaire consisting of a of 30 questions regarding nutritional needs, how to choose good food and food safety. This instrument was tried out and validated prior to the data collection. The questionnaire was filled by each respondent accompanied by a pretrained enumerator.

Behavior was assessed in four stages. The first stage was to determine intake of energy and macronutrients by using a single 24-H food recall and analyzed using Indonesian food composition table. The second stage was comparing to individual needs to find out any compatibility. The third stage was assessing the suitability of the proportion of energy intake and macronutrients with balanced nutrition principles. The fourth stage was assessing implementation of food safety by using a questionnaire consisting of 20 questions about food safety behavior. The fourth step considered as behavior was assessed twice, before and after the intervention.

The intervention group received nutrition education in the first week by providing booklet 1 containing indi- 
Table 1. Energy Intake, Intake Score, Dietary Habit Score and Food Safety

\begin{tabular}{|c|c|c|c|c|c|c|c|}
\hline Variable & Category & $\begin{array}{l}\text { Before Intervention } \\
\text { Mean } \pm(\text { SD })\end{array}$ & p value & $\begin{array}{l}\text { After Intervention } \\
\text { Mean } \pm(\text { SD) }\end{array}$ & p value & Mean $\pm($ SD $)$ & p value ${ }^{a}$ \\
\hline \multirow[t]{2}{*}{ Energy intake (Kkal) } & Intervention $(\mathrm{n}=25)$ & $1666 \pm(220)$ & \multirow[t]{2}{*}{0.622} & $1722 \pm(184)$ & $0.002^{*}$ & $56.04 \pm(125.27)$ & \multirow[t]{2}{*}{0.944} \\
\hline & Control $(n=29)$ & $1683 \pm(229)$ & & $1736 \pm(181)$ & 0.050 & $53.03 \pm(177.40)$ & \\
\hline \multirow[t]{2}{*}{ Intake score ${ }^{b}$} & Intervention $(\mathrm{n}=25)$ & $64.00 \pm(16.26)$ & \multirow[t]{2}{*}{0.284} & $74.00 \pm(16.26)$ & $0.002^{*}$ & $10.00 \pm(14.43)$ & \multirow[t]{2}{*}{0.345} \\
\hline & Control $(n=29)$ & $68.96 \pm(17.23)$ & & $75.00 \pm(17.67)$ & 0.050 & $6.03 \pm(15.88)$ & \\
\hline \multirow[t]{2}{*}{ Dietary habit score ${ }^{c}$} & Intervention $(\mathrm{n}=25)$ & $52.00 \pm(10.00)$ & \multirow[t]{2}{*}{0.011} & $68.00 \pm(10.00)$ & $0.003^{*}$ & $16.00 \pm(23.80)$ & \multirow[t]{2}{*}{0.55} \\
\hline & Control $(n=29)$ & $56.89 \pm(17.54)$ & & $60.34 \pm(17.67)$ & 0.424 & $3.44 \pm(22.87)$ & \\
\hline \multirow[t]{2}{*}{ Food safety $\mathrm{d}$} & Intervention $(\mathrm{n}=25)$ & $82.80 \pm(13.07)$ & \multirow[t]{2}{*}{0.991} & $89.20 \pm(10.00)$ & $0.015^{*}$ & $6.40 \pm(12.20)$ & \multirow[t]{2}{*}{$0.015^{*}$} \\
\hline & Control $(n=29)$ & $82.75 \pm(13.86)$ & & $81.72 \pm(11.04)$ & 0.522 & $-1.03 \pm(8.59)$ & \\
\hline
\end{tabular}

*p $<0.05$

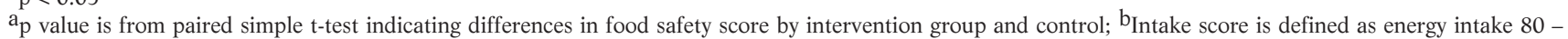
$110 \%$ from energy needs (score 100) and energy intake $<80 \%$ and $>110 \%$ from energy needs (score 50 ); ${ }^{\mathrm{c}}$ Dietary habit score is defined from score 100 if it suitable from balance diet composition for energy and macronutrient, score 75 if it suitable from balance diet composition for energy or macronutrient, score 50 if it unsuitable from balance diet composition for both of energy or macronutrient; ${ }^{\mathrm{d}}$ Food safety is defined as scrore based on questionnaire and it contains score 0 100 .

Table 2. Knowledge and Behavior

\begin{tabular}{|c|c|c|c|c|c|c|c|}
\hline Variable & Category & $\begin{array}{l}\text { Before Intervention } \\
\text { Mean } \pm(\text { SD })\end{array}$ & p value & $\begin{array}{l}\text { After Intervention } \\
\text { Mean } \pm(\text { SD) }\end{array}$ & p value & Mean $\pm(S D)$ & p value ${ }^{a}$ \\
\hline \multirow[t]{2}{*}{ Knowledge ${ }^{b}$} & Intervention $(\mathrm{n}=25)$ & $81,20 \pm(17,15)$ & \multirow[t]{2}{*}{0,111} & $89,60 \pm(17,15)$ & 0,000 & $8,40 \pm(9,4)$ & \multirow[t]{2}{*}{$0,000^{*}$} \\
\hline & Control $(n=29)$ & $87,58 \pm(11,54)$ & & $86,55 \pm(8,97)$ & 0,477 & $-1,03 \pm(7,7)$ & \\
\hline \multirow[t]{2}{*}{ Behavior $^{b}$} & Intervention $(\mathrm{n}=25)$ & $66,24 \pm(8,68)$ & \multirow[t]{2}{*}{0,166} & $73,64 \pm(13,45)$ & 0,000 & $7,50 \pm(8,71)$ & \multirow[t]{2}{*}{$0,049 *$} \\
\hline & Control $(n=29)$ & $69,55 \pm(8,59)$ & & $72,00 \pm(11,04)$ & 0,171 & $2,55 \pm(9,40)$ & \\
\hline
\end{tabular}

*P value $=0.05$

ap value is from paired simple t-test indicating differences in food safety score by intervention group and control; ${ }^{b}$ Knowledge is defined as score based on questionnaire and it contains score $0-100$; ${ }^{c}$ Behavior is defined as score based on average score from intake, dietary habit and implementation of food safety.

vidual nutritional needs and the list of foodstuff exchanger. At the second week, the respondents attended nutrition counseling and to evaluate the implementation of nutritional advice. In the third week, the respondents came for the second nutrition education by getting booklet 2 containing guidance to choose any good food for daily eating and booklet 3 containing food security. In the fourth week, the respondents were evaluated. The control group were only asked to come during the pretest and received a flyer containing the recommended balanced nutrition and during posttest for the next four weeks. According to standard procedures, the balanced nutrition flyer was distributed in accordance with HIV patients without nutritional problems.

\section{Results}

\section{Characteristics of Samples}

Demographic data was defined by characteristics including age, sex, education, occupation and family support. Respondents in the age of 20 to 59 years in which $57 \%$ were $30-39$ years old $(n=31)$. Based on gender, women respondents were $56.4 \%(\mathrm{n}=31)$. The respondents who attained high school were $18(72 \%)$ in the treatment group and $19(65.5 \%)$ in the control group. Most respondents were employed and having regular in- come $(60 \%)$ in the treatment group and $17(58.5 \%)$ in the control group. Respondents worked as teacher, employee, non-governmental organization (NGO) workers and labors. Family support/peer group were $21(84 \%)$ in the treatment group, and $23(79.3 \%)$ in the control group. There was no any significant difference according to the characteristics between those two groups of respondents ( $\mathrm{p}$ value $>0.05$ )

\section{Knowledge and Behavior}

According to Table 1, knowledge and behavior showed charateristics as well as proportion above specified reference values.

Before the intervention, there was no signficant difference for both groups in energy intake, dietary habit and food safety implementation. After intervention, there were significant changes found in energy intake in the treatment group $(p$ value $=0.002)$, energy intake score $(p$ value $=0.002)$, diet $(\mathrm{p}$ value $=0.003)$ and food safety $(\mathrm{p}$ value $=0.015$ ). The differences before and after the intervention in both groups were seen in the implementation of food safety ( $\mathrm{p}$ value $=0.015$ ). Table 2 included results of subsitution from the fourth part of values above as behavior and knowledge before the intervention. There was no significant difference in knowledge and be- 
havior in both groups. After the intervention, the result showed significant differences of knowledge and behavior and no significant differences for control group that stated the same condition for each group.

\section{Discussion}

There were $56.4 \%$ women included in this study. According to Indonesian HIV/AIDS statistical data, there were $30 \%$ of women living with HIV/AIDS until December 2013.9 If it is associated with HIV, women are much easier to experience epidemic than men related to biological, sociocultural and economic reasons. ${ }^{10}$ The education levels in this study were senior high school $68.5 \%$ and the remaining was both secondary school and college. Education level may influence behavior in choosing his/her lifestyle, particularly related to food and nutrition. In the study that took students as samples, there was a relation between parents' education level and their children's nutritional status. Education took a part in influencing food provision in the household level. 10 About $59 \%$ of diverse occupations was described in this study. They were private employees, teachers, volunteers at community social institution, labors, and self-employed. People work to fulfill their daily needs including food by expanding their job income. According to the Joint United Nations Programme on HIV/AIDS (UNAIDS) 2002, treatment costs for PLWHA can discard family's savings much more than the deaths caused by ailments in a short time or an accident. Family sustainability will disappear, especially when the parents (of PLWHA) are died. ${ }^{11}$ About $81 \%$ of the total of sample gain support from their family. Family support is one of the important non-pharmacological therapy for someone potentially suffers from depression. ${ }^{12}$

The pretest resulted no difference of knowledge between the two groups were found before the intervention $(\mathrm{p}$ value $=0.111)$. After nutrition intervention was performed to the treatment group, this group had changed $(\mathrm{p}$ value $=0.000)$, while the control group which was not performed intervention had not changed ( $p$ value $=0.477)$. The comparison of value change was statistically different $(\mathrm{p}$ value $=0.000)$. It means there was any influence of performing nutrition education and counseling in enhancing knowledge of PLWHA. Knowledge is a factor that contributes to create a behavior. It is usually obtained from the involvement of seeing and hearing sense. These senses become important domain in creating behavior. ${ }^{13}$ Study conducted in West France among adult men showed there was a relation between eating pattern knowledge and food choice related to eating behavior. ${ }^{7}$

Study conducted in Uganda among women with HIV positive showed performing nutrition education and knowledge regarding nutritious foodstuffs perceived ef- fectively work through grouping foodstuffs approach, for example, each group of flour, source of protein, fruits, vegetables and food in accordance with season. This method was able to improve their knowledge about foodstuffs $(\mathrm{p}$ value $=0.006)$ and eating schedule $(\mathrm{p}$ value $=$ 0.002). ${ }^{14}$ The result was in accordance with this study showing the answer upon the questions about that group did not know energy source food declining to $36 \%$ from $44 \%$. Likewise, that group did not know vitamin source food declining to $24 \%$ from $36 \%$ after intervention was performed. This study also obtained difference result of 9 right answers of 10 questions between the treatment group and the control group.

The study using the theory of planned behavior to influence the food consumption behavior found that respondents who were well-informed about food additive and processed food had a positive food consumption attitude to those kinds of food. It also showed that there was a difference of the food containing additives selection between the well-informed group and the less-informed group $(\mathrm{p}$ value $=0.002) .{ }^{15}$ The study of adult attitude to milk consumption had concluded that nutrition education needed to focus on the behavior changes and diminishing any barriers which affected their consumption of milk. ${ }^{16}$ In such theory of planned behavior, attitude is a way in the direction of behavior. The attitude is formed as a degree for people to evaluate which behavior that will give advantage or disadvantage and good or bad for them to take a decision toward behavior. When someone considered the processed food and food contained additives were safe to consume, they would have the intention to consume those kinds of food. Somehow that attitude was also controlled by the norms surround them. ${ }^{3}$ The study results on PLWH had found that there were attitude changes to the implementation of food security education for PLWH. The education support used problem-solving approach for common problems and motivation support from the health personals. ${ }^{13}$

The three kinds of behavior assessed in this study contained intake adequacy compared to the individual needs, food source selection and food security. Applied daily skills to handle food and beverage, the capacity to overcome the food access and ability of food preparation were behaviors that became a concern in this study. ${ }^{17}$ Particular lessons were needed in order to get the desired skills. The objective of the lessons was supplying the knowledge as provisions to change someone's behavior. The study had shown that there was no difference of the nutrient intake in the after and before the intervention for both groups ( $p$ value $=0.622)$, meanwhile after the intervention, there was a difference of nutrient intake of the exposed group $(\mathrm{p}$ value $=0.002)$. Nutritional needs topic as the nutrition education aimed to improve nutrient intakes of PLWH. The result in eating pattern had 
shown that there was a difference in eating pattern after nutrition intervention ( $p$ value $=0.003$ ). From the answered questions by the PLWH, there were significant differences on the answers of questions related to the attention of packaged food and beverage, the way to store raw foods and the food selection while eating out. The results were also in line with the study on food security after the intervention ( $\mathrm{p}$ value $=0.015$ ). Food security for PLWH really needs special attention because they are very susceptible to food-related infectious disease, such as chronic diarrhea which can exacerbate their condition. Usually, such condition derived from the raw food consumption or half-cooked food consumption. Several ways to avoid that condition are by processing every food until it is fully-cooked before eating, particularly food like meats, fishes, poultries; storing the food sources carefully to avoid the cross-contamination; and boiling the water. Therefore, the right knowledge of food security is needed. ${ }^{18}$

After these three aspects were observed, the results showed that behavior had changed, by the intervention such as education and counseling ( $p$ value $=0.015$ ). This kind of behavioral change is one of the basic skills for living healthier, though they need another compliant aspect like taking an ARV. Study of the women's group in Uganda had shown that the food selection pattern in the household level had changed after they received the training about the importance of nutrition for PLWH and balance nutrient knowledge. The flour consumption is higher than the fruits and protein source prior to the study. The relation between knowledge support of skills to differ each food source by their group, nutrition comprehension $(\mathrm{p}$ value $=0.006$ ) and eating schedule had been proven significant $(\mathrm{p}$ value $=0.002) .{ }^{18}$

\section{Conclusion}

As a conclusion, nutrition education has a significant relation with the increasing nutrition knowledge and behavior. Nutrition intervention as a part of nutrition care as processed by providing nutrition education and counseling may increase nutrition knowledge and behavior of PLWH. Continuous education is a good method to be gradually provided in accordance with the needs of the PLWH and it can be sustainable. Since PLWH are in healthy condition, the provision of education is needed because this can help maintain their condition. Therefore, this should be immediately implemented before they come with nutritional problems.

\section{Recommendation}

Nutrition counseling on nutrition education should be provided to support the establishment of good nutrition behavior and help PLWH to face problems related to nutrition. Supportive and collaborative process between client and counselor in improving food, nutrition and physical activities in which the individual goals and plans are approved by the client will help to organize individual treatment plans as addressed to achieve optimal health.

\section{References}

1. Food and Nutrition Technical Assistance Academy for Educational Development. Guide for nutritional care and support [online]. 2nd ed. Washington DC: Academy for Educational Development; 2004 [cited 2015 Jan 4]. Available from: http://reliefweb.int/sites/ reliefweb.int/files/resources/C7B4ADF3EC3927E5C125740C003D03 D9-fanta_oct2004.pdf.

2. Ivers LC, Cullen KA, Freedberg KA, Block S, Coates J, Webb P. HIV/AIDS, undernutrition, and food insecurity, clinical infectious disease. Clinical Infectious Disease. 2009; 49: 1096 - 102.

3. Kementerian Kesehatan Republik Indonesia. Pedoman pelayanan gizi bagi ODHA. Direktorat Bina Gizi Masyarakat. Jakarta: Direktorat Jenderal Bina Kesehatan Masyarakat Kementerian Kesehatan Republik Indonesia; 2010.

4. Mahan L, Stump SE, Raymond JL. Krause's food and the nutrition care process. $13^{\text {th }}$ ed. St. Louis: Elsevier; 2012.

5. Krishan S, Schouen JT, Atkinson B, Brown T, Wohl D, McComsey GA, et al. Metabolic syndrome before and after inititation of antiretroviral therapy in treatment-naive HIV infected individuals. Journal of Acquired Immune Deficiency Syndrom. 2012 November 1; 61 (3): 381-9.

6. Kagaruki GB, Kimaro DG, Mweya NC, Kilale MA, Mrisho MR, Shao FA, et al. Prevalence and risk factors of metabolic syndrome among individuals living with HIV and receiving antiretroviral treatment in Tanzania. British Journal of Medicine and Medical Reseach. 2015 [cited 2015 May 5]; 5 (10): 1317-27. Available from: http://www.sciencedomain.org/downloads/Njc5N0BAR2lic29uNTEwMjAxNEJKTU1SMT Q0NTUucGRm

7. Venter E, Gericke GJ, Bekker PJ. Nutritional status, quality of life and cd4 cell count of adult living with HIV/AIDS in the Ga-Rankusa Are (South Africa). South Africa Journal of Clinical Nutrition. 2009; 22 (3): 124-9.

8. Hayes C, Elliot E, Krales E, Downer G. Food and water safety fo person infected with Human Immunodeficiency Virus. Clinical Infectious Disease [serial on internet]. 2003 [cited 2014 Jan 5]; 36 (Supplement 2): S106-9. Available from: .www.ncbi.nlm.nih.gov/pubmed/12652380

9. American of Nutrition and Dietetics. International dietetics and nutrition terminology (IDNT) reference manual: standardized language for the nutrition care process. 4th ed. Chicago: Academy of Nutrition and Dietetics; 2013.

10. Kim K, Reicks M, Sjoberg S. Applying the theory of planned behavior to predict dairy product consumption by older adults. Journal of Nutrition and Education Behavior. 2003 Nov-Dec; 35 (6): 294-301. Available from: www.ncbi.nlm.nih.gov/pubmed/14642214.

11. Seo S, Kim Oy, Shim S. Using the theory of planned behavior to determine factors influencing processed foods consumption behavior. Nutrition Research Practice. 2014 Jun; 8 (3): 327-35.

12. Castleman T, Deitchler M, Tumilowicz. Aguide to monitoring and evaluation of nutrition assessment, education and counseling of peple living 
with HIV. Washington: Food and Nutrition Technical Assistance Project. Academi for Educational Development; 2008 [cited 2015 Jan 5]. Available: http://pdf.usaid.gov/pdf_docs/Pnadm260.pdf

13. Bauer Kathleen, Liou D, Sokolik CA. Nutrition counseling and education skill development. 2nd ed. Wadsworth: Cengage Learning; 2012.

14. Nelms MN, Surchers K, Lacey KK, Sara RL. Nutrition therapy and phatophysiology. 2nd ed. Wadsworth: Cengage Learning; 2010.

15. International Labour Organization/World Health Organization. Pedoman bersama ILO/WHO tentang pelayanan kesehatan dan HIV/AIDS [online]. Jakarta: Direktorat Pengawasan Kesehatan Kerja, Departemen Tenaga Kerja dan Transmigrasi Republik Indonesia; 2005 [cited 2015 Feb 4]. Available from: http://www.who.int/hiv/pub/guidelines/who_ilo_guidelines_indonesian.pdf.
16. Kementerian Kesehatan Republik Indonesia. Data kumulatif HIV/AIDS [online]. Jakarta: Direktorat Jenderal Pemberantasan Penyakit dan Penyahatan Lingkungan Kementerian Kesehatan Republik Indonesia; 2013 [cited 2015 Jan 5]. Available from: http://spiritia.or.id/Stats/StatCurr.pdf.

17. Hoffman EW, Berqmann V, Shultz JA, Kendall P, Medeiros LC, Hillers N. Application of a five step message development model food safety education materials targeting people with HIV/AIDS. Journal of American Dietetic Association. 2005; 105: 1597 - 604.

18. Bukusuba J, Kikafunda JK, Whitehead RG. Nutritional knowledge attitudes, and practices of women living with HIV in Eastern Uganda. Journal of Health Population and Nutrition. April 2010; 28 (2): 182-8. 